Original Research Article

\title{
Evaluation and comparison of anti-cancer activity of dapagliflozin and canagliflozin in oral cancer cell line: an in vitro study
}

\author{
Nenavath Vinay, Darling Chellathai David*
}

Department of Pharmacology, Sri Ramachandra Medical College and Research Institute, Chennai, Tamil Nadu, India

Received: 10 January 2019 Accepted: 30 January 2019

*Correspondence to: Dr. Darling Chellathai David, Email: daviddolly@ rediffmail.com

Copyright: (C) the author(s), publisher and licensee Medip Academy. This is an openaccess article distributed under the terms of the Creative Commons Attribution NonCommercial License, which permits unrestricted noncommercial use, distribution, and reproduction in any medium, provided the original work is properly cited.

\begin{abstract}
Background: Cancer is rapidly evolving life-threatening ailment in the mankind due to changes in daily food intake and lifestyle changes. Oral carcinoma is $6^{\text {th }}$ major cause of cancer death in the world and it is third major reason of cancer mortality in India. Every cell in the human body requires glucose for its metabolic energy. Besides normal cell, cancer cells also require the glucose for its endurance and multiplication. SGLT2 inhibitors which are aimed at diabetes therapy exhibited anticancer properties also in colon and pancreatic cancer lines. Present study aim is to evaluate the anticancer activity of SGLT2 inhibitors against oral cancer cell by MTT Assay.

Methods: To evaluate the anticancer activity of SGLT2 inhibitors MTT Cytotoxic assay is performed as per standard protocols. Cancer cells were plated in 24-well plates and incubated at $37^{\circ} \mathrm{C}$ with $5 \% \quad \mathrm{CO}_{2}$ condition. After convergence, samples are added to the plates in various concentrations and allowed to incubate then they are detached from the plates and cleansed with the reagents. The wells are coated with the dye and incubated. Later samples are analysed in UV-spectrophotometer.

Results: Cytotoxic assay showed decrease in cell viability with increasing dose of SGLT2 inhibitors. IC 50 values were determined graphically. The $\mathrm{IC}_{50}$ value of dapagliflozin is $400 \mu \mathrm{g} / \mathrm{ml}$ and canagliflozin is $250 \mu \mathrm{g} / \mathrm{ml}$ respectively after 24 hours of Assessment.

Conclusions: The results of the current study give us an evidence that SGLT2 inhibitors dapagliflozin and canagliflozin exhibits anticancer property in Oral Cancer cell line.
\end{abstract}

Keywords: Canagliflozin, Dapagliflozin, Oral cancer, MTT Assay, SGLT2 inhibitors

\section{INTRODUCTION}

In the current scenario of massive variations in daily regime of humans across globe and owing to these a lifethreatening ailment called cancer is evolving swiftly. Cancer is due to loss of cell cycle control associated with abnormal and uncontainable cell growth. ${ }^{1}$ Today cancer is one of the foremost reasons of the deaths. Among all cancers in the world oral carcinoma stands sixth, it is one among leading three causes of cancer in India with low survival rate of mankind. ${ }^{2,3}$ There is increased prevalence of premalignant oral lesions in the diabetes patients leading to oral cancer. ${ }^{4}$ This oral squamous cell carcinoma classically affects middle age cluster adults who are at consistent acquaintance to tobacco, betel, liquor or micronutrients deficit. ${ }^{5}$ Now-a-days even younger age group patients are affected with oral cancer. The primary onset of oral cancer is sited at base of tongue, tonsils, oropharynx.

Every cell of human body need glucose aimed at its endurance and it is main provider of metabolic energy. Glucose is adopted into the cytosol compartment where it is exposed to glycolysis intended to produce pyruvate that is altered into acetyl Co-A for ATP production in mitochondria. Nevertheless, glucose remains a hydrophilic complex besides in order to passage through the 
phospholipid bilayer, precise conveyance proteins are essential, such as sodium glucose co-transporters (SGLT). ${ }^{6}$ Other than normal cells, glucose stands the foremost provider of metabolic energy in tumour cells, which articulated transformed glucose uptake by means of amplified necessity intended for glycolysis or Warburg effect. $^{7}$ With excess production of glucose in diabetic patients, malignant cells accept more glucose besides duplication happens subsequently oral malignancy prevalence is high in these people.

In humans, plasma glucose is filtered inside kidney glomerulus then a reuptake progression stays trailed via sodium glucose co-transporters SGLT1 and SGLT2 ensuing a high reabsorption proportion close to $99 \% .^{8,9}$ SGLT2 stands as high capacity transporters expressed in the proximal tubule of the nephron and possibly will be backing near $90 \%$ of glucose reabsorption. Hence, SGLT2 inhibitors such as canagliflozin and dapagliflozin lately acknowledged excessive consideration as novel medications intended for the treatment of type II diabetes. Dapagliflozin and canagliflozin SGLT2 inhibitors are chosen for this study since they are metabolically steady, in disparity to further SGLT2 inhibitors such as phlorizin which is inapt for drug development due to its low bioavailability and swift hydrolysis in the kidney. ${ }^{8,10}$

A recent work showed that SGLT2 transporters are functionally expressed in prostrate and adenocarcinoma of pancreas and that SGLT2 inhibitors may hinder glucose acceptance and, in that way, reduced malignant cancer progress and improved existence in a xenograft model of pancreatic cancer. ${ }^{11}$ Hence, SGLT2 inhibitors might demonstrate beneficial in tumour healing.

In this work, the effect of SGLT2 inhibitors on KB cells examined using MTT cytotoxic assay and to compare both dapagliflozin and canagliflozin to see which has better activity in this study.

\section{METHODS}

\section{Molecule, cell lines and culture}

Dapagliflozin molecule is procured from AstraZeneca India. Canagliflozin molecule is acquired from Manus Akkteva Biopharma LLP, Ahmedabad. From National Centre for Cell Sciences, Pune the KB cell lines procured and conserved in Minimal Essential Medium augmented alongside Penicillin 100U/ml, 10\% FBS besides Streptomycin $100 \mu \mathrm{g} / \mathrm{ml}$ in $50 \mu \mathrm{g} / \mathrm{ml} \mathrm{CO}_{2}$ at moistened temperature $37^{\circ} \mathrm{C}$.

\section{Reagents}

MEM was purchased from Hi Media Laboratories. Fetal Bovine Serum was procured from Cistron Laboratories. 3(4,5-dimethyl-2-thiazolyl)-2,5-diphenyl tetrazolium bromide (MTT), Trypsin and Dimethyl Sulfoxide (DMSO) were procured from Sisco Research laboratory situated in Mumbai. All other components and chemicals were obtained from Sigma-Aldrich Inc, Mumbai.

\section{In vitro assay for anticancer activity (MTT Assay)}

The cytotoxic activity of dapagliflozin and canagliflozin on KB Cancer Cells was determined by MTT assay. ${ }^{12} \mathrm{~KB}$ Cells $1 \times 10^{5}$ per each well were seeded in 24 -well plates and nurtured at $37^{\circ} \mathrm{C}$ with $5 \%$ carbon dioxide condition. Later the cell ranges the convergence, several concentrations of test samples of dapagliflozin, canagliflozin and standard drug 5-Fluorouracil were added from minimum to maximum $1000 \mu \mathrm{g} / \mathrm{ml}$ and nurtured for $24 \mathrm{hrs}$. After nurture, samples were detached from welled plates and cleansed by means of saline buffered with phosphate of $\mathrm{pH} 7.4$ or MEM deprived of serum. $100 \mu \mathrm{l}$ per each well $(5 \mathrm{mg} / \mathrm{ml})$ of $0.5 \%$ MTT salt was supplemented and allowed to incubate 4 hours. Later, a volume of $1 \mathrm{ml}$ DMSO was supplemented in entire well plate. The absorbance measured at $570 \mathrm{~nm}$ wavelength by means of UV-Spectrophotometer with DMSO in place of blank. Measurements were detected, and the concentration essential for a $50 \%$ dilution $\left(\mathrm{IC}_{50}\right)$ was plotted on graph paper. The viability of cells percentage is obtained by calculation using equation:

Viability of cells percentage $=$ A570 of preserved cells / A570 of control cells $\times 100$

Graph plotted with cell viability percentage on Y-axis and concentration of test sample on $\mathrm{X}$-axis. Cell control and sample control is contained within each assay to compare the complete cell viability valuations.

\section{RESULTS}

From the results of MTT Assay we perceive that there remained diminution in cell viability by intensification of concentration.

Table 1: Anticancer effect of sample dapagliflozin on $\mathrm{KB}$ cell line.

\begin{tabular}{|lll|l|}
\hline $\begin{array}{l}\text { Concentration } \\
(\mu \mathrm{g} / \mathrm{ml})\end{array}$ & Dilutions & $\begin{array}{l}\text { Absorbance } \\
(\mathbf{O} . \mathbf{D})\end{array}$ & $\begin{array}{l}\text { Cell } \\
\text { viability } \\
(\%)\end{array}$ \\
\hline 1000 & Neat & 0.183 & 35.74 \\
\hline 500 & $1: 1$ & 0.237 & 46.28 \\
\hline 250 & $1: 2$ & 0.291 & 56.83 \\
\hline 125 & $1: 4$ & 0.339 & 66.21 \\
\hline 62.5 & $1: 8$ & 0.391 & 76.36 \\
\hline 31.2 & $1: 16$ & 0.416 & 81.25 \\
\hline 15.6 & $1: 32$ & 0.441 & 86.13 \\
\hline 7.8 & $1: 64$ & 0.457 & 89.25 \\
\hline Cell control & - & 0.512 & 100 \\
\hline
\end{tabular}

Dapagliflozin displayed maximum cell viability as $89.25 \%$ (minimum cell inhibition as $11.75 \%$ ) at $7.8 \mu \mathrm{g} / \mathrm{ml}$ concentration of dapagliflozin after 24 hours of assay with 
KB Cell line and the minimum cell viability is $35.74 \%$ (maximum cell inhibition is $64.26 \%$ ) at $1000 \mu \mathrm{g} / \mathrm{ml}$ concentration of dapagliflozin after 24 hours assay (Table $1)$.

\section{Table 2: Anticancer effect of sample canagliflozin on $\mathrm{KB}$ cell line.}

\begin{tabular}{|llll|}
\hline $\begin{array}{l}\text { Concentration } \\
(\boldsymbol{\mu g} / \mathrm{ml})\end{array}$ & Dilutions & $\begin{array}{l}\text { Absorbance } \\
(\mathbf{O . D})\end{array}$ & $\begin{array}{l}\text { Cell } \\
\text { viability } \\
(\%)\end{array}$ \\
\hline 1000 & Neat & 0.129 & 25.19 \\
\hline 500 & $1: 1$ & 0.194 & 37.89 \\
\hline 250 & $1: 2$ & 0.275 & 53.71 \\
\hline 125 & $1: 4$ & 0.328 & 64.06 \\
\hline 62.5 & $1: 8$ & 0.375 & 73.24 \\
\hline 31.2 & $1: 16$ & 0.418 & 81.64 \\
\hline 15.6 & $1: 32$ & 0.438 & 85.54 \\
\hline 7.8 & $1: 64$ & 0.452 & 88.28 \\
\hline Cell control & - & 0.512 & 100 \\
\hline
\end{tabular}

Table 3: Anticancer effect of 5-flurouracil on KB cell line.

\begin{tabular}{|llll|}
\hline $\begin{array}{l}\text { Concentration } \\
(\boldsymbol{\mu g} / \mathrm{ml})\end{array}$ & Dilutions & $\begin{array}{l}\text { Absorbance } \\
(\mathbf{O . D})\end{array}$ & $\begin{array}{l}\text { Cell } \\
\text { viability } \\
(\%)\end{array}$ \\
\hline 1000 & Neat & 0.011 & 6.9 \\
\hline 500 & $1: 1$ & 0.024 & 11.34 \\
\hline 250 & $1: 2$ & 0.077 & 18.75 \\
\hline 125 & $1: 4$ & 0.114 & 24.98 \\
\hline 62.5 & $1: 8$ & 0.183 & 48.90 \\
\hline 31.2 & $1: 16$ & 0.263 & 54.78 \\
\hline 15.6 & $1: 32$ & 0.368 & 69.87 \\
\hline 7.8 & $1: 64$ & 0.475 & 78.56 \\
\hline Cell control & - & 0.512 & 100 \\
\hline
\end{tabular}

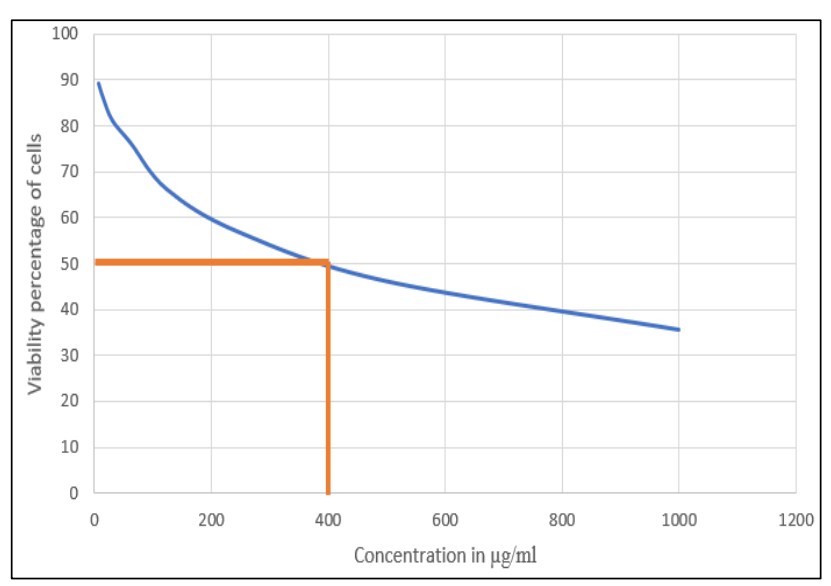

Figure 1: Cell viability assay of dapagliflozin against KB cell line.

Canagliflozin maximum cell viability is $88.28 \%$ (minimum cell inhibition is $11.72 \%$ ) at $7.8 \mu \mathrm{g} / \mathrm{ml}$ concentration of canagliflozin after 24 hours and the minimum cell viability is $25.21 \%$ (maximum cell inhibition is $74.79 \%$ ) at $1000 \mu \mathrm{g} / \mathrm{ml}$ concentration of canagliflozin after 24 hours of assay (Table 2). The maximum and minimum cell viability for 5 -fluorouracil is $72.85 \%$ at $7.8 \mu \mathrm{g} / \mathrm{ml}$ concentration and $4.9 \%$ at $1000 \mu \mathrm{g} / \mathrm{ml}$ concentration respectively (Table 3). The inhibitory concentration $\left(\mathrm{IC}_{50}\right)$ at half maximum value of dapagliflozin is ascertained at $400 \mu \mathrm{g} / \mathrm{ml}$ and $\mathrm{IC}_{50}$ Value of canagliflozin is ascertained at $250 \mu \mathrm{g} / \mathrm{ml}$ after 24 hours of assessment. The $\mathrm{IC}_{50}$ value of 5-Fluorouracil is $58 \mu \mathrm{g} / \mathrm{ml}$. The $\mathrm{IC}_{50}$ values are depicted in the figures (Figure 1 and 2).

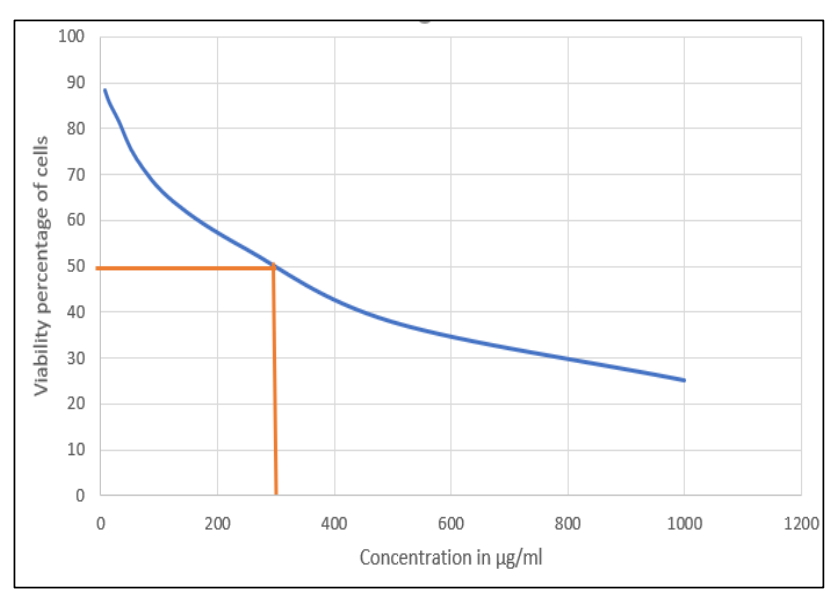

Figure 2: Cell viability assay of canagliflozin against $\mathrm{KB}$ cell line.

\section{DISCUSSION}

Apart from modulating sodium glucose transport inhibition in diabetic patients, SGLT2 inhibitors exhibited anticancer activity in colon and pancreatic cancer cells in a recent study by Scafoglio et al, done on dapagliflozin and canagliflozin, this phenomenon might be due to inhibition of SGLT2 intermediated glucose uptake. ${ }^{11}$ However, standalone restriction of glucose uptake is not enough to reduce cell viability/progression. ${ }^{13}$ Hence it is not clear if this is the chief mechanism by which SGLT2 inhibitors restrict growth. A recent study by Villani et al, stated canagliflozin triggered AMPK by constraining mitochondrial respiration in human embryonic kidney cells. Canagliflozin prevents both glucose acceptance and complex - I reinforced respiration concurrently, this twin mechanism of action may be significant for facilitating the inhibitory properties of propagation. ${ }^{14}$ The encounter of a novel mechanism of glucose transportation in cancer rises the interrogation of the importance of these SGLT equated by the previously renowned GLUT- dependent glucose acceptance. ${ }^{15,16}$ The key change amongst GLUTs besides SGLTs is that while GLUTs passage glucose down the concentration slope, SGLTs connect the sodium rise crosswise the plasma membrane to initiate glucose acceptance, namely sodium-glucose cotransport. Consequently, the dynamism for glucose cotransport is gained indirectly from ATP pouring the $\mathrm{Na} / \mathrm{K}$ pump used to uphold the sodium incline over plasma membrane. ${ }^{17,18}$ In epithelial cells, GLUTs and SGLTs are conveyed in 
distinct apical, basolateral and plasma membranes, nevertheless in tumour cells the dispersal and comparative status of the two forms of glucose transporters are not until now identified. It is likely that in tumour cells, GLUT1 and SGLT2 canal glucose in the direction of diverse cellular partitions and metabolic paths, together with mitochondrial oxidation, the pentose phosphate pathway, aerobic glycolysis, and the hexosamine path. ${ }^{19,20}$

In a recent study by Saito et al, it has been reported that dapagliflozin was inhibiting the glucose uptake of cancer cells and causing cytotoxicity. ${ }^{13}$ Correspondingly in our study canagliflozin and dapagliflozin also have shown significant loss of cell viability in oral squamous cell carcinoma KB cell lines at concentrations of $250 \mu \mathrm{g} / \mathrm{ml}$ and $400 \mu \mathrm{g} / \mathrm{ml}$ in comparison with standard drug 5-fluorouracil, also we have detected the cells underwent reduction and decline in number exhibiting positive cytotoxic activity and the probable mechanism would be because of the restriction of glucose uptake and curbing Mitochondrial intracellular ATP synthesis thereby limiting the cell cycle of cancer cells. ${ }^{21}$ In present study canagliflozin was more cytotoxic than dapagliflozin in $\mathrm{KB}$ cell line as established by $\mathrm{IC}_{50}$ values.

\section{CONCLUSION}

This study establishes that SGLT2 inhibitors has encouraging cytotoxic action against oral squamous cancer $\mathrm{KB}$ cell line with canagliflozin unveiling more cytotoxicity than dapagliflozin and both drugs have potential to be used as anticancer agents in cancer therapy nevertheless further in vivo studies are required.

\section{Funding: No funding sources \\ Conflict of interest: None declared \\ Ethical approval: Not required}

\section{REFERENCES}

1. World Health Organization. Fact sheet: Cancer, 12 September 2018. Available at: https://www.who.int/en/news-room/factsheets/detail/cancer. Accessed 19 December 2018.

2. Gupta N, Gupta R, Acharya AK, Patthi B, Goud V, Reddy $\mathrm{S}$, et al. Changing Trends in oral cancer-a global scenario. Nepal J Epidemiol. 2016 Dec;6(4):613.

3. Mallath MK, Taylor DG, Badwe RA, Rath GK, Shanta $\mathrm{V}$, Pramesh CS, et al. The growing burden of cancer in India: epidemiology and social context. Lancet Oncol. 2014 May 1;15(6):e205-12.

4. Auluck A. Diabetes mellitus: an emerging risk factor for oral cancer?. J Canadian Dental Assoc. 2007;73(6):501-3.

5. Rao SV, Mejia G, Roberts-Thomson K, Logan R. Epidemiology of oral cancer in Asia in the past decade-an update (2000-2012). Asian Pacific J Cancer Prevention. 2013;14(10):5567-77.
6. Szablewski L. Expression of glucose transporters in cancers. Biochim Biophys Acta. 1835;2013:164-9.

7. Zhang D, Li J, Wang F, Hu J, Wang S, Sun Y. 2Deoxy-D-glucose targeting of glucose metabolism in cancer cells as a potential therapy. Cancer Lett. 2014 Dec 28;355(2):176-83.

8. Obermeier M, Yao M, Khanna A, Koplowitz B, Zhu $\mathrm{M}, \mathrm{Li} \mathrm{W}$, et al. In vitro characterization and pharmacokinetics of dapagliflozin (BMS-512148), a potent sodium-glucose cotransporter type II inhibitor, in animals and humans. Drug Metab Disposition. 2010 Mar 1;38(3):405-14.

9. Li LT, Zhou LF, Li YJ, Huang J, Liu RH, Wang B, et al. Facile synthesis of 1, 2, 3-triazole analogs of SGLT2 inhibitors by 'click chemistry'. Bioorganic Medicinal Chem Lett. 2012 Jan 1;22(1):642-4.

10. Angelopoulou A, Voulgari E, Kolokithas-Ntoukas A, Bakandritsos A, Avgoustakis K. Magnetic Nanoparticles for the Delivery of Dapagliflozin to Hypoxic Tumors: Physicochemical Characterization and Cell Studies. AAPS Pharm Sci Tech. 2018 Feb 1;19(2):621-33.

11. Scafoglio C, Hirayama BA, Kepe V, Liu J, Ghezzi C, Satyamurthy $\mathrm{N}$, et al. Functional expression of sodium-glucose transporters in cancer. Proceed National Acad Sci. 2015 Jul 28;112(30):E4111-9.

12. Mosmann T. Rapid colorimetric assay for cellular growth and survival: application to proliferation and cytotoxicity assays. J Immunol Methods. 1983;65:5563.

13. Saito T, Okada S, Yamada E, Shimoda Y, Osaki A, Tagaya Y, et al. Effect of dapagliflozin on colon cancer cell [rapid communication]. Endocrine J. 2015;62(12):1133-7.

14. Villani LA, Smith BK, Marcinko K, Ford RJ, Broadfield LA, Green AE, et al. The diabetes medication Canagliflozin reduces cancer cell proliferation by inhibiting mitochondrial complex-I supported respiration. Molecular Metabolism. 2016 Oct 1;5(10):1048-56.

15. Ganapathy V, Thangaraju M, Prasad PD. Nutrient transporters in cancer: relevance to Warburg hypothesis and beyond. Pharmacol Therapeutics. 2009 Jan 1;121(1):29-40.

16. Szablewski L. Expression of glucose transporters in cancers. Biochim Biophys Acta. 2013 Apr;1835(2):164-9.

17. Amy SY, Hirayama BA, Timbol G, Liu J, Basarah E, Kepe V, et al. Functional expression of SGLTs in rat brain. Am J Physiol Cell Physiol. 2010 Dec;299(6):C1277.

18. Amy SY, Hirayama BA, Timbol G, Liu J, DiezSampedro A, Kepe V, et al. Regional distribution of SGLT activity in rat brain in vivo. Am J Physiol Cell Physiol. 2013 Feb 1;304(3):C240.

19. Itkonen HM, Minner S, Guldvik IJ, Sandmann MJ, Tsourlakis MC, Berge V, et al. O-GlcNAc transferase integrates metabolic pathways to regulate the stability of c-MYC in human prostate cancer cells. Cancer Res. 2013 May 29. 
20. Ying H, Kimmelman AC, Lyssiotis CA, Hua S, Chu GC, Fletcher-Sananikone E, et al. Oncogenic Kras maintains pancreatic tumors through regulation of anabolic glucose metabolism. Cell. $2012 \mathrm{Apr}$ 27;149(3):656-70.

21. Shivpuje P, Ammanangi R, Bhat K, Katti S. Effect of ocimum sanctum on oral cancer cell line: an in vitro study. J Contemp Dental Practice. 2015 Sep;16(9):709-14.

Cite this article as: Nenavath V, Chellathai DD. Evaluation and comparison of anti-cancer activity of dapagliflozin and canagliflozin in oral cancer cell line: an in vitro study. Int J Basic Clin Pharmacol 2019;8:473-7. 